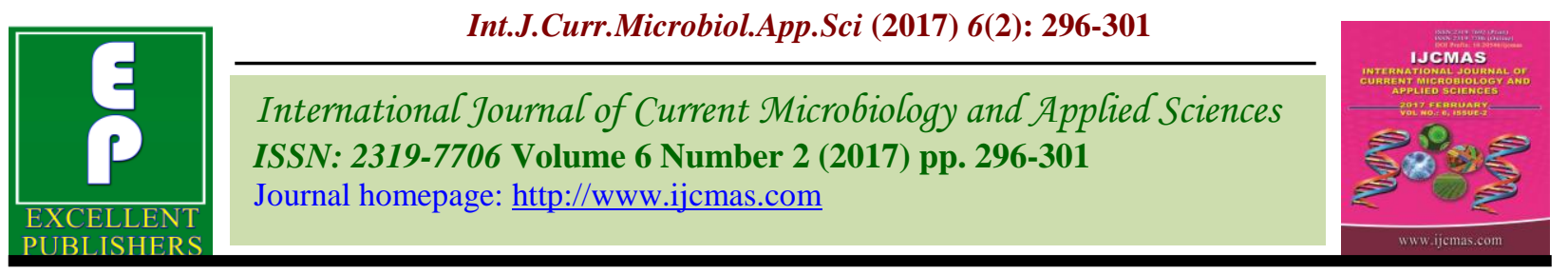

Original Research Article

http://dx.doi.org/10.20546/ijcmas.2017.602.035

\title{
Effect of Supplementation of Amla Powder on Biochemical Parameters in Summer Stressed Murrah Buffaloes
}

\author{
Preeti Lakhani*, Rajesh Jindal and Shashi Nayyar \\ Department of Veterinary Physiology and Biochemistry, GADVASU, Ludhiana, India - 141004 \\ *Corresponding author
}

\author{
A B S T R A C T
}

The effect of amla powder supplementation was investigated on biochemical parameters in summer stressed buffaloes. The study was carried out with 24 apparently healthy Murrah

Keywords

Amla,

Antioxidant status,

Biochemical

parameters. buffaloes during pre-summer and summer seasons. The results revealed that the plasma glucose, creatinine, urea and bilirubin were significantly higher in Summer Control group (Group II) as compared to Pre-Summer group (Group I), clearly confirming the adverse effect of summer stress and on supplementation with antioxidant (vitamin $\mathrm{C}$ in the form of amla powder) to Summer Treatment group (Group III) buffaloes, there was decrease in plasma glucose, creatinine, urea and bilirubin. Plasma Protein and plasma cholesterol were found to be significantly lower in summer control group (Group II) as compared to presummer group (Group I) and there was increase in Plasma Protein and plasma cholesterol in Group III (summer treatment group) as compared to Group II (summer control group) on supplementation with antioxidant (vitamin $\mathrm{C}$ in the form of amla powder). Biochemical parameters showed negative and significant correlation $(\mathrm{P}<0.05)$ with Temperature Humidity Index (THI) except cholesterol and urea. Thus, it can be concluded that amla powder supplemented to heat stress buffaloes can be useful in order to maintain biochemical parameters.

\section{Introduction}

Buffalo is well suited to tropical regions; it exhibits signs of distress when exposed to hot and humid weather conditions. In terms of Temperature Humidity Index (THI), the value $>68.5$ is considered as stressful and >83.5 is considered very severe heat stress to buffaloes. This is due to the fact that buffalo's body absorbs a great deal of solar radiation because of its dark skin, sparse hair coat and less efficient evaporative cooling system (Das et al., 1999). Exposure of buffaloes to the hot conditions evokes a series of drastic changes in biological functions (Marai and Habeeb, 2010). Heat stress occurs in an animal when there is an imbalance between heat production within the body and its dissipation. Stress is the state manifested by a specific syndrome, which consists of all the non-specifically induced changes within a biological system. Both external and internal stressors cause pronounced behavioral, physiological and hematological alterations in tropical livestock. Environmental stress has a profound effect on some biochemical parameters (Marai and Habeeb, 2010).

Recently, use of antioxidant supplementation in order to enhance the endogenous 
antioxidant capacity of animal has been of interest in various species. Vitamin $\mathrm{C}$ is a classic example of antioxidants and its supplementation has been found to ameliorate the heat stress in goats (Kumar 2009), cows (Ul-Haq et al., 2013) and buffaloes (Sunilkumar et al., 2010). Therefore, use of amla powder as an antioxidant can be of practical importance to ameliorate the adverse effect of heat stress in buffaloes. No work seems to have been done on such beneficial effects of amla powder supplementation in buffaloes. Therefore, the present study was planned.

\section{Materials and Methods}

The study was conducted on 24 apparently healthy adult female Murrah buffaloes maintained under standard management conditions during pre-summer (March-April; Mean $\mathrm{THI}=68.5$ ) and summer (June -August; Mean $\mathrm{THI}=83.5$ ) seasons. The animals were divided into three groups of 8 each viz. PreSummer group (group I): No supplementation; Summer Control Group (Group II): No supplementation; Summer Treatment Group (Group III): Supplemented with amla powder @ $200 \mathrm{mg} / \mathrm{Kg}$ body wt. / day for 30 days. The biochemical parameters viz., Plasma glucose level was estimated by standard technique using Siemens Autopak kits on RA50 chemistry analyser by glucose oxidase / per oxidases method as described by Trinder (1969).

Total protein level in plasma was estimated by using Siemens Autopak kits on RA50 chemistry analyser by Biuret method (Henry et al., 1974). Plasma cholesterol estimation was done by enzymatic method using Siemens Autopak kits on RA50 chemistry analyser by CHOD/PAP method described by Allain et al., (1974). Plasma creatinine was estimated by Picrate method using Siemens Autopak kits on RA50 chemistry analyser as described by Henry et al., (1974). Total bilirubin in plasma was analysed by kinetic method using Siemens Autopak kits on RA50 chemistry analyser. Plasma urea was estimated by kinetic method using Siemens Autopak kits on fully automatic biochemistry analyser.

The data were subjected to analysis of variance (ANOVA) for comparison of means among different groups, and group-differences were detected by the Fisher's least-significantdifference test. All analyses were performed with the statistics package SYSTAT VERSION 6.0.1 Copyright (c) 1996, SPSS INC.

\section{Results and Discussion}

\section{Plasma Glucose}

Studies revealed that mean plasma glucose concentration was found to be higher in summer stressed buffaloes (Group II) as compared to pre summer group (Group I) probably due to the greater catabolic effect of corticosterone, and increased gluconeogenesis yielding more of glucose (Sahin et al., 2003). The higher glucose level in heat stress buffaloes is in agreement with the studies conducted by Singh et al., (2008) in ewes, Chaiyabuter et al., (1987) in buffaloes and by Marai et al., (1992) in mature Ossimi ewes.

Plasma glucose concentration in treatment group buffaloes (Group III) supplemented with amla powder was significantly $(\mathrm{P}<0.05)$ lowered as compared to Group II (summer control group). The decrease in the glucose concentration in Group III may be due to the effect of antioxidant activity on the insulin and corticosterone levels, as ascorbic acid supplementation increases insulin concentration and decreases corticosterone level (Sahin et al., 2003). Significantly decreased plasma glucose level $(\mathrm{P}<0.05)$ in 
Group III indicates the positive effectiveness of amla powder supplementation on reverting the adverse effect caused by heat stress. Similar findings on effect of amla powder have been reported by Ul-Haq et al., (2013) on crossbred cattle.

No significant difference in the mean levels of plasma glucose concentration was observed between Group I and Group III suggesting that amla supplementation @ $200 \mathrm{mg} / \mathrm{kg}$ body weight was sufficient to bring the plasma glucose level back to normal pre summer levels justifying the positive effect of supplementation of amla powder in relieving the effects of heat stress in buffaloes.

\section{Plasma Total protein}

Mean plasma total protein concentration was lower in Group II as compared to Group I. The significant decline in plasma total protein with rising temperature seems to be due to decrease of protein synthesis as a result of depression of anabolic hormonal secretion (El-Masry and Habeeb, 1989). Similar findings were reported by Yousef (1985) and Ronchi et al., (1995) in Egyptian buffalo calves and Friesian heifers respectively and Verma et al., (2000) in lactating Murrah buffaloes. Das et al., (2013) reported that plasma protein in Nili-Ravi lactating buffaloes was slightly lower during hot humid season indicating a decline in total protein with increase in environmental stress.

\section{Plasma cholesterol}

Result revealed lowered level of cholesterol in Group II to as compared Group I. Similar decrease in plasma cholesterol level with heat stress has been reported by Gudev et al., (2007) during summer season.

Table.1 Biochemical parameters in summer stressed buffaloes supplemented with amla powder

\begin{tabular}{|c|c|c|c|c|c|c|}
\hline \multirow[b]{2}{*}{ Groups } & \multicolumn{6}{|c|}{ Biochemical Parameters } \\
\hline & $\begin{array}{l}\text { Plasma } \\
\text { glucose } \\
(\mathrm{mg} / \mathrm{dl})\end{array}$ & $\begin{array}{l}\text { Plasma } \\
\text { protein } \\
(\mathrm{g} \%)\end{array}$ & $\begin{array}{c}\text { Plasma } \\
\text { cholesterol } \\
(\mathrm{mg} / \mathrm{dl})\end{array}$ & $\begin{array}{c}\text { Plasma } \\
\text { creatinine } \\
(\mathrm{mg} / \mathrm{dl})\end{array}$ & $\begin{array}{l}\text { Plasma urea } \\
(\mathrm{mg} / \mathrm{dl})\end{array}$ & $\begin{array}{c}\text { Plasma } \\
\text { bilirubin } \\
(\mathrm{mg} / \mathrm{dl})\end{array}$ \\
\hline $\begin{array}{c}\text { I } \\
\text { Pre-Summer } \\
\text { group }\end{array}$ & $52.78 \pm 2.76^{\mathrm{a}}$ & $6.90 \pm 0.14^{\mathrm{a}}$ & $137.39 \pm 6.19^{\mathrm{a}}$ & $1.02 \pm .09$ & $32.39 \pm 0.89^{\mathrm{a}}$ & $0.64 \pm 0.32^{\mathrm{a}}$ \\
\hline $\begin{array}{c}\text { II } \\
\text { Summer } \\
\text { Control Group }\end{array}$ & $75.00 \pm 4.05^{\mathrm{b}}$ & $5.07 \pm 0.28^{\mathrm{b}}$ & $129.78 \pm 5.52^{\mathrm{b}}$ & $1.23 \pm 0.10$ & $37.11 \pm 1.38^{b}$ & $0.72 \pm 0.23^{b}$ \\
\hline $\begin{array}{c}\text { III } \\
\text { Summer } \\
\text { Treatment } \\
\text { Group: } \\
\text { (supplemented } \\
\text { with amla } \\
\text { powder @ 200 } \\
\text { mg/Kg body } \\
\text { wt./day }\end{array}$ & $51.11 \pm 2.96^{\mathrm{a}}$ & $6.51 \pm 0.14^{\mathrm{a}}$ & $133.06 \pm 3.31^{\mathrm{a}}$ & $1.24 \pm 0.12$ & $30.61 \pm 1.00^{\mathrm{a}}$ & $0.65 \pm 0.22^{\mathrm{a}}$ \\
\hline
\end{tabular}

Means bearing different superscripts $(a, b, c)$ differ significantly $(\mathrm{P}<0.05)$ within the columns 
Table. 2 Correlation of Temperature Humidity Index (THI) with Biochemical parameters in summer stressed buffaloes supplemented with amla powder

\begin{tabular}{|l|l|l|l|l|l|l|l|}
\hline \multicolumn{1}{|c|}{ Parameters } & \multicolumn{1}{|c|}{ THI } & $\begin{array}{c}\text { Plasma } \\
\text { glucose }\end{array}$ & $\begin{array}{c}\text { Plasma } \\
\text { protein }\end{array}$ & $\begin{array}{c}\text { Plasma } \\
\text { cholestero } \\
1\end{array}$ & $\begin{array}{c}\text { Plasma } \\
\text { creatinine }\end{array}$ & $\begin{array}{c}\text { Plasm } \\
\text { a urea }\end{array}$ & $\begin{array}{c}\text { Plasma } \\
\text { bilirubin }\end{array}$ \\
\hline \multicolumn{1}{|c|}{ THI } & 1.000 & & & & & & \\
\hline Plasma glucose & $-0.442 * *$ & 1.000 & & & & & \\
\hline Plasma protein & $-0.398 * *$ & 0.152 & 1.000 & & & & \\
\hline $\begin{array}{l}\text { Plasma } \\
\text { cholesterol }\end{array}$ & -0.103 & -0.025 & -0.217 & 1.000 & & & \\
\hline $\begin{array}{l}\text { Plasma } \\
\text { creatinine }\end{array}$ & $-0.474 * *$ & -0.265 & -0.192 & -0.183 & 1.000 & & \\
\hline Plasma urea & -0.155 & 0.138 & 0.193 & 0.254 & -0.125 & 1.000 & \\
\hline Plasma bilirubin & $\mathbf{- 0 . 4 6 7 * *}$ & 0.134 & 0.162 & -0.135 & $-0.487 * *$ & 0.154 & 1.000 \\
\hline
\end{tabular}

Das et al., (2013) reported negative impact of summer stress on plasma cholesterol. As observed that an increase in mean plasma cholesterol concentration with supplementation of amla powder indicates a positive effect of amla. Similar finding were reported by Kumar et al., (2010) and Randhawa (2013) in goats.

\section{Total bilirubin}

Bilirubin is an endogenous compound and is the ultimate breakdown product of haemoglobin. Total bilirubin concentration $(\mathrm{mg} / \mathrm{dl})$ was significantly $(\mathrm{p}<0.05)$ higher in Group-II as compared to pre summer group indicating the adverse effects of summer heat stress on buffaloes. Similar findings have been reported by Cincovic et al., (2011) in Holstein cows. With supplementation of amla, the bilirubin level was restored close to presummer values.

\section{Creatinine and Urea}

There was significant $(\mathrm{p}<0.05)$ increase in plasma creatinine and urea concentrations during summer as compared to pre summer season. Under heat stress conditions, there is more reabsorption of urea- $\mathrm{N}$ from the blood to the rumen in order to compensate for the decrease in rumen ammonia $-\mathrm{N}$ as a result of decrease in feed intake and digestible nitrogen consumption, which could lead to increase in blood urea nitrogen (BUN) associated with heat stress (Yousef, 1985). Habeeb et al., (2007) reported a significant increase in creatinine concentration under heat stress conditions in Egyptian buffaloes. Gudev et al., (2007) reported that plasma urea level tended to be higher $(\mathrm{P}>0.05)$ when the heat load was the highest could be due to the negative effect of the elevated core temperature on rumen micro-flora activity. On supplementation of amla powder, there was significant decrease in plasma urea level in Group III. However no significant change in plasma level of creatinine was observed.

\section{References}

Allain, C.C., Poon, L.S. and Chan, C.S.G. 1974. Enzymatic determination of total serum cholesterol. Clin. 
Chem., 20: 470 -75.

Chaiyabuter, N., Buranakari, C., Muangcharoen, V., Loypetjra, P. and Pichaicharnarong, A. 1987. Effects of acute heat stress on changes in the rate of liquid flow from the rumen and turnover of body water of swamp buffalo (Bubalus bubalis) J. Agric. Sci. (Comb.), 77: 549-53.

Cincovic, M.R., Belic, B., Toholj, B., Potkonjak, A., Stevancevic, M., Lako, B. and Radovic, I. 2011. Metabolic acclimation to heat stress in farm housed Holstein cows with different body condition scores. African $J$. Biotechnol., 10(50): 10293-303.

Das, K.S., Singh, J.K., Singh, G. and Nayan, V. 2013. Effect of heat stress alleviation on plasma protein, metabolites and lipid profile in lactating Nili-Ravi buffaloes under tropical climate Indian J. Anim. Sci., 83(5): 546-49.

Das, S.K., Upadhyaya, R.C., Madan, M.L. 1999. Heat stress in Murrah buffalo calves. Livestock Prod. Sci., 61: 71-78.

El-Masry, K.A. and Habeeb, A.A. 1989. Thyroid function in lactating Friesian cows and water buffaloes under winter and summer Egyptian conditions. In: Proceedings of $3^{\text {rd }}$ Egyptian-British Conference on Animal, Fish and Poultry Production, Alexandria, Egypt. 2:61320.

Gudev, D., Popva-Ralcheva, S., Moneva, P., Alekseiv, Y., Peeva, T., Ilieva, P. and Penchev, P. 2007. Effect of heat-stress on some physiological and biochemical parameters in buffaloes. Ital. J. Anim. Sci., 6, (Suppl. 2), 1325-28.

Habeeb, A.A.M., Fatma, F.I.T and Osman, S.F. 2007. Detection of heat adoptability using heat shock proteins and some hormones in Egyptian Buffalo calves. Egypt J. Appl. Sci., 22(2A): 2853.

Henry, R.J., Cannon, D.C., Winkelman, W.
1974. Clinical Chemistry Principles and Techniques, 11th ed. Harper and Row, p. 1629.

Kumar, M. 2009. Reproductive performance and blood biochemical profile of summer stressed goats following antioxidant supplementation. M.V.Sc. Thesis, submitted to Guru Angad Dev Veterinary \& Animal Science University, Ludhiana, India.

Kumar, M., Jindal, R., Nayyar, S. and Singla, M. 2010. Physiological and biochemical responses in beetal goats during summer season. Indian J. Small Rum., 16(1): 255-257.

Marai, I.F.M. and Habeeb, A.A.M. 2010. Buffaloes Reproductive and Productive traits as affected by heat stress. Tropical and Subtropical Agro ecosystems, 12: 193-217.

Marai, I.F.M., Daader, A.H., Makkawy, M.Y., Gaber, H.A. and Ibrahim, H. 1992. Effect of housing syatem, season of year and age on some physiological parameters and blood constituents of Ossimi sheep. J. Arid Environ., 22: 27785.

Randhawa, H.K. 2013. Effect of amla powder supplementation on physiological and blood biochemical responses in heat stressed goats. M.V.Sc. Thesis. Guru Angad Dev Veterinary and Animal Sciences University, Ludhiana, India.

Ronchi, B., Bernabucci, U., Lacetera, N.G., Nardine, A. and Bertoni, G. 1995. Effects of heat stress on metabolic status of Friesian heifer. Zootechnica-eNutizione-Animale, 21: 209-21.

Sahin, K., Onderci, M., Sahin, N., Gursu, M.F. and Kucuk, O. 2003. Dietary vitamin $\mathrm{C}$ and folic acid supplementation ameliorates the detrimental effects of heat stress in Japanese quail. J. Nutr., 133: 1882-86.

Singh, D.N., Wadhwani, K.N., Arya, J.S., Sarvaiya, N.P. and Patel, A.M. 2008. 
Effect of housing systems on blood constituents of ewes during summer in a subtropical climate. Indian J. Small Ruminants, 14(2): 252-254

Sunilkumar, B.V., Singh, G. and Meur, S.K. 2010. Effects of addition of electrolyte and ascorbic acid in feed during heat stress in buffaloes. Asian Aust. J. Anim. Sci., 23(7): 880-888.

Trinder, P. 1969. Determination of glucose in blood using glucose oxidase with an alternative oxygen acceptor. Annal of Clin. Biochem., 6(1): 24-27.
Ul-Haq, A., Konwar, D. and Khan, A. 2013. Effect of supplementation of ascorbic acid and amla powder on hematobiochemical parameters in crossbred dairy cows. Indian J. Anim. Nutr., 30(1): 33-37.

Verma, D.N., Lal, S.N., Singh, S.P., Prakash, O.M., and Prakash, O. 2000. Effect of season on biological responses and productivity of buffalo. Int. J. Anim. Sci., 15(2): 237-44.

Yousef, M.K. 1985. "Stress Physiology in livestock" (CRC Press, Boca Raton, FL, USA).

\section{How to cite this article:}

Preeti Lakhani, Rajesh Jindal and Shashi Nayyar. 2017. Effect of Supplementation of Amla Powder on Biochemical Parameters in Summer Stressed Murrah Buffaloes. Int.J.Curr.Microbiol.App.Sci. 6(2): 296-301. doi: http://dx.doi.org/10.20546/ijcmas.2017.602.035 